\title{
VÉGTELEN TÖRTÉNET: A NARRATÍV ELEMZÉS ALKALMAZHATÓSÁGA A MARKETINGKUTATÁSBAN
}

A cikk arra keresi a választ, hogy a narratív közelítés hogyan alkalmazható az akadémiai marketingkutatásokban, ezzel színesítve a kicsit szegényesnek mondható módszertani palettát. A narratív gondolkodásmódból kiindulva a filozófiát visszatükröző kutatási irányzatokat mutat be a fogyasztói magatartás, valamint a reklámkutatás területén. Bár a cikk elsősorban marketingproblémákat vizsgál, a közelítés kiválóan alkalmazható a többi menedzsmentdiszciplínában is.

\begin{abstract}
„Életünk legnagyobb részét olyan világban éljük, amely a narratív eszközöknek és szabályoknak megfelelöen épül fel."
\end{abstract}

(Jerome Bruner)

Mindennapjainkban történetek vesznek körül. Ébredés után talán emlékszünk éjszakai álmunkra, $\mathrm{s}$ a rádiót bekapcsolva hírekben számolnak be arról, hogy kivel mi történt. A műsorvezető szórakoztató történetekkel próbálja fenntartani a hallgatóság érdeklődést. A kávéscsészére pillantva eszünkbe jut az a történet, hogy a nagyitól kaptuk valamelyik születésnapunkra, s pillanatra felidézzük a szereplőket. Kinyitjuk az újságot, $\mathrm{s}$ újabb történetek árasztanak el bennünket: történetek a gazdasági és politikai helyzetről, az árfolyammozgásról vagy a hétvégi mérkőzés eseményeiről. Hirdetéseken siklunk át, amelyek arról számolnak be, hogy miért jó az adott márkát használni. Kicsit elmerengünk az egyik képen látható luxusautó láttán és csukjuk is be az újságot, mert éppen megszólal a telefon és a vonal végén egy hang arról érdeklődik, hogy mi van velünk.

Azt, hogy a történetek mindenhol jelen vannak, Barthes (1977:79) így foglalja össze: ,a narratívum jelen van a mítoszban, a legendában, a mesében, a novellában, az epikában, a történelemben, a tragédiában, a drámában, a komédiában, a táncban, a festészetben, [...] az ónüveg ablakokon, a moziban, a képregényekben, az újságcikkekben, a beszélgetésekben. E szinte végtelen változatosságban a narratívum jelen van minden korban, minden helyszínen, minden társadalom- ban. A narratívum az emberiség történetével kezdődik, és soha, sehol sem éltek emberek, akiknek az életében ne játszott volna szerepet. A narratívum átível a kultúrákon és a történelmen."

Történetekben élünk és a történetek éltetnek minket. Az események a történetek elmondásával újra és újra átélhetők. Miért van mégis, hogy ezt módszertani szempontból nem vesszük észre? Talán éppen azért, mert áthatja életünk minden egyes rezdülését, s túlságosan is nyilvánvalónak tűnik.

Az érdekes az, hogy a marketing gyakorlati alkalmazásában - és különösen a reklámban - a történeteket kiválóan alkalmazzák márkaépítésre, mítoszteremtésre. A jó történetek az egekbe röpíthetnek $(\mathrm{pl}$. Marlboro), míg a gyengék márkákat rombolhatnak le. Magyarországon azonban a marketing tudományos élet meglehetősen szűkölködik módszertani eszköztárban, a klasszikus mainstream vonalat követve dominálnak a kvantitatív kutatások, mintha egy-egy problémához kizárólag egyféleképpen lehetne hozzányúlni. A tudományos kutatások még azt a módszertani változatosságot sem képesek megközelíteni, ami a piaci alkalmazott kutatásokban megfigyelhető, nem beszélve a nemzetközi trendekről. A cikk célja, hogy színesítse a kutatások metodológiai palettáját.

\section{Narratív paradigma}

Az elmúlt évtizedekben a társadalom- és a humántudományok területén egyre inkább felismerik, hogy a 
társas tudást, a szociális gondolkodást a természetes logikára emlékeztető narrativitás jellemzi (László, 2005:94). A narratológia a hatvanas években, a strukturalista irodalomtudományban szerveződött önálló kutatási irányzattá, azonban az elmúlt évtizedekben multidiszciplináris tudományterületté vált, ahol a strukturális elemzés mellett az elbeszélések interpretációja is figyelmet kapott (Onega - Landa, 1996).

S ez nem csupán az olyan „mesélős” tudományok esetén figyelhető meg, mint a néprajz, hanem más, a paradigmatikus gondolkodás logikáját követő társadalomtudományok, mint a szociológia, a pszichológia vagy akár a közgazdaságtan sem lehetnek mentesek a narrativitás elemeitől (László, 2005:104). Robert Heilbroner, a Közgazdaságról közérthetöen c. könyv szerzője megjegyezte, hogy amikor a gazdaságelméletre alapozott előrelátás csütörtököt mond, kollégáival együtt sztorizni kezd a japán menedzserekről, a zürichi „,kígyóról”, vagy a Bank of England „eltökéltségéről”, mondván ez gátat vet a font sterling zuhanásának (Bruner, 2001:55). Modigliani és Miller híres tételét, amely szerint a tőkestruktúra változása nem változtatja meg egy vállalat bevételét és nyereségét, Miller az alábbi hasonlattal tette érthetőbbé: „Ha egy pizzát nyolc szeletre vágunk fel, attól még ugyanúgy pizza marad.” Adam Smith egy gombostűkészítő manufaktúra történetén keresztül mutatja be a munkamegosztás előnyeit, Marchék pedig szemetesvödör-modellről beszélnek, amikor anarchikus szituációban lévő döntést akarják bemutatni. Úgy tűnik, igaza van Brunernek (2004:115), aki szerint ,,a nagy tudományos elméletek a vártnál történetszerűbbek”.

\section{A gondolkodás két útjának összevetése}

\begin{tabular}{|l|l|l|}
\hline Emberkép & \multicolumn{1}{|c|}{$\begin{array}{c}\text { Paradigmatikus } \\
\text { (logikai-tudományos) mód }\end{array}$} & \multicolumn{1}{c|}{ Narratív mód } \\
\hline Világkép & $\begin{array}{l}\text { Az emberek alapvetően } \\
\text { racionális lények } \\
\text { A világ logikai kirakós játék }\end{array}$ & $\begin{array}{l}\text { Az emberek alapvetően } \\
\text { történetmesélők } \\
\text { A világ történetekből áll }\end{array}$ \\
\hline Megítélés alapja & $\begin{array}{l}\text { A tudományos elméleteket vagy } \\
\text { a logikai bizonyításokat a veri- } \\
\text { fikálhatóságuk és tesztelhetősé- } \\
\text { gük alapján }\end{array}$ & $\begin{array}{l}\text { A történeteket a valóságosságuk } \\
\text { vagy életszerüségük alapján }\end{array}$ \\
\hline Magyarázóeszköz & Matematika, logika & Irodalom \\
\hline Kedvelt eszköz & $\begin{array}{l}\text { Hipotézis, amely ha jól megfor- } \\
\text { málják, törékeny }\end{array}$ & Történetek interpretálása. \\
\hline Világ megismerése & $\begin{array}{l}\text { Spekulatív modelleken, közve- } \\
\text { tett módszereken keresztül }\end{array}$ & $\begin{array}{l}\text { Történeteken, metaforákon, } \\
\text { meséken keresztül }\end{array}$ \\
\hline Eredmény & $\begin{array}{l}\text { Mind magasabb szintű absztrak- } \\
\text { ció }\end{array}$ & $\begin{array}{l}\text { Jó történetek, felkavaró drámák, } \\
\text { hihető (bár nem feltétlenül } \\
\text {,igaz”) történeti beszámolók }\end{array}$ \\
\hline
\end{tabular}

Forrás: Bruner (2001), 27-29. old.; Fisher (1984) alapján
Az elbeszéléseknek a természetes mindenütt jelenvalósága miatt Bruner (2001) a narratívumot nem csupán a kommunikáció, hanem az emberi gondolkodás sajátos műfajának is tekinti, megkülönböztetve a logikus vagy paradigmatikus gondolkodástól (1. táblázat). A gondolkodás paradigmatikus vagy logikai-tudományos módja elvont fogalmakkal dolgozik, az igazságot formális logikai eljárásokkal és tapasztalati bizonyítékok révén tételezi, s eközben olyan oksági viszonyokat keres, amelyek egyetemleges igazságfeltételekhez vezetnek. Ezzel szemben a gondolkodás elbeszélő módja „világiasabb”, emberi vagy humán jellegű szándékokat és tetteket, az ezekkel kapcsolatos történéseket és következményeket vizsgálja. Az életszerüséggel igazolja magát, és nem az igazság, hanem az élethűség kialakítására törekszik (László - Thomka, 2001).

„Mivel mindannyian elbeszéléseket élünk meg életünk során, és mivel elbeszélések segítségével értelmezzük saját megélt életünket, ezért alkalmas a narratív forma mások cselekedeteinek a megértésére" (MacIntyre, 1999:284). László (2005:13) szerint az elbeszélés kellően rugalmas, ugyanakkor kellően stabil képződmény ahhoz, hogy meghatározott kérdésekre vonatkozó tudományos elemzés kiindulópontja legyen. Az elbeszélés megteremti saját kereteit, s ezáltal alkalmas arra, hogy objektív, tudományos vizsgálat tárgyává tegyük (László, 2005:15).

A narratív paradigma is képes arra, hogy új, eddig fogalmilag nem kezelt tapasztalatokat is kezeljen, mint az érzések és képek, vagy az idő és a perspektíva (László, 2005:98). Amikor történetek olvasunk, nem pusztán a cselekvések idejét és helyét értjük meg, hanem el tudjuk képzelni a helyszínt és a fószereplőt is (Oatley, 1992). Bele tudjuk magunkat képzelni a szituációba, és azonosulni tudunk a főszereplő érzéseivel, legyen az öröm vagy bánat

Sarbin (2001:59) szerint „a narratívum azonos jelentésü a történettel, ahogyan azt a hétköznapi beszélők használják. Egy történet időbeli kiterjedésű szimbolikus számadás az emberi cselekvésekről. Egy történetnek van kezdete, közepe és befejezése, de legalább a „befejezettség érzetét" kelti. A történet események mintázatából áll, ez a cselekmény. A cselekmény szerkezetének központi vonása, hogy benne emberi nehézségeket a megoldásukra tett próbálkozások követik.” László (2005) úgy 
véli, hogy a narratív gondolkodás legnyilvánvalóbb megjelenési formái a hivatásos szerzők és az átlagemberek által mondott történetek.

\section{Narratív elemzés helye a kutatásmódszertan palettáján}

A narratív technikát alapvetően a kvalitatív kutatások közé soroljuk ${ }^{1}$ A kvalitatív kutatás meghatározására Banister et al. (1994:3, idézi Ehmann, 2003:81) definícióját fogadjuk el: „a kvalitatív kutatás egy vita része, nem rögzített igazság. A kvalitatív kutatás kísérlet arra, hogy megragadjuk a mélyben rejlö értelmet, és ez strukturálja mindazt, amit arról mondunk, amit csinálunk." Vagyis kísérletet tehetünk a mélyben rejlő értelem feltárására és strukturálására, de abszolút igazságokat nem mondhatunk ki. A kvalitatív kutatás jelenleg abban a szakaszban van, ahol „,az elméleteket is narrativ terminusokban olvassuk, mint afféle, a terepről hozott mendemondákat (tales from the field)" (Van Maanen, 1988:11).

A kvalitatív kutatást gyakran az interpretatív jelzővel illetik, itt azonban inkább Gummesson (2003) álláspontjával értünk egyet, aki egyenesen azt állítja, hogy minden kutatás interpretatív. Egyetlen kutatás sem olyan, mint az automatából kiugró üdítő, vagyis ha elég pénzt dobunk bele, s megnyomjuk a megfeleló gombot, akkor kijön a megfelelő termék. Az interpretáció ugyanis áthatja az egész kutatási folyamatot, a legelejétől a legvégéig. Mind a szavakat, mind pedig a számokat értelmezni kell. Gummesson (2003) szerint már az is, hogy mit kutatunk, milyen kutatási kérdéseket teszünk fel, s hogyan találjuk meg rájuk a választ - azt jelenti, hogy miként interpretáljuk a világot.

Tashakkori és Teddlie (1998) szerint a kvalitatív és kvantitatív módszerek valójában kompatibilisek, s a paradigmaháború gyakorlatilag véget ért. Ha ez a magyar menedzsmentirodalomra is igaz, akkor a háború még azelőtt befejeződött, mielőtt kitört volna. Radácsi (2003) szerint a hazai menedzsmentkutatások messze nem mutatják azt az elméleti és módszertani sokszínűséget, ami a nemzetközi szakirodalomban évtizedek óta megfigyelhető. Bár menedzsmentben az utóbbi években már születtek kizárólag kvalitatív kutatásra épülő átfogó munkák (Bokor, 2000; Gelei, 2001), az akadémiai marketing területén ez nem igazán jellemző. A „hazai” marketingirodalomban a kvalitatív módszereket (amely gyakorlatilag leszúkül mélyinterjúra és fókuszcsoportra) inkább a kvantitatív kutatást megelőző lépésként tartják számon (Malhotra, 2001), amelyek képtelenek önmagukban megállni.

Nem gondoljuk azt, hogy egyik paradigma felette áll a másiknak, inkább abban hiszünk, hogy a módszerek kiválóan kiegészíthetik egymást, $\mathrm{s}$ meg kell próbálni mindig az aktuális problémának megfelelő módszereket találni. Feyerabend (1975) azt javasolja a kutatóknak, hogy ne ragadjanak benn módszertani rítusokban, hanem válasszanak olyan eszközöket, amelyek a legjobban illeszkednek a kutatott problémához.

Bár a narratív közelítés jelentőségét a marketingben és a reklámban már többen kiemelték (pl. Bush - Bush, 1994; Hirschman, 1986; Stern, 1988, 1995), azonban Magyarországon a tudományos életben ez eddig még nem honosodott meg. A tudományszociológusok (Haraway, 1984; Mulkay, 1985) rávilágítottak arra, hogy a tudomány világa éppúgy a ,jó” történetekre fogékony, mint a társadalmi kommunikáció egyéb területei. Haraway (1984) szerint az emberi társadalomban egy adott korban a lehetséges világok korlátozott készlete él. Ezek a lehetséges világok - mint elfogadott jelentésrendszerek - jelentős mértékben befolyásolják, hogy adott időszakban egy tudományban mi és hogyan mondható el, vagyis mi számít jó történetnek.

Azok a történetek tehát, amelyek nem számítanak jónak, elvesznek, hiszen nem mennek át a hihetőség szűrőjén. A mainstream által determinált logika nehezen fogad el olyan gondolkodásmódokat, amely nem illeszkedik be az addig követett irányvonalba. Wittgenstein kifejezésével élve a tudomány is nyelvjáték, amelynek a sakkhoz hasonlóan megvannak a maga szabályai. Ha valaki ezek alapján játszik, az tudományosan gondolkodik és érvel (Heller, 1997).

Az elmúlt száz évben azonban számos tudománytörténész rámutatott arra, hogy a tudósok az intuíciók, a történetek, a metaforák egész hadát hívják segítségül azért, hogy spekulatív modelljük minél jobban illeszkedjen a természethez. Annyi metaforát, hatásos alakzatot, mesét és egyebet használtak fel, amennyit csak találnak (Bruner, 2004: 116). Gerald Holton tudománytörténész például leírja, hogy a tudósok kezdetektől fogva a narratívumok, metaforák, történetek segítségére támaszkodnak - kígyók, amelyek lenyelik saját farkukat; mi tartja a Földet stb. (Bruner, 2004: 117). S valószínúleg ezek sokkal könnyebben megjegyezhetők, mint a tízszer tízes mátrixok vagy a kusza, áttekinthetetlen, azonban rendkívül tudományosnak tűnő modellek.

\section{Fogyasztáshoz kapcsolódó történetek elemzési lehetőségei}

$$
\begin{aligned}
& \text { „Találd meg a sztorit a termékben - mondd el } \\
& \text { világosan és meggyözően!” }
\end{aligned}
$$

(Bill Bernbach)

Bernbach rájött arra, hogy a sikerhez nem elég, ha a hirdetés a termékről szól, s nem szabad passzív közönségként kezelni az embereket, hanem párbeszédet 
kell kialakítani velük (Steel, 2002: 31). Vagyis olyan hihető történeteket kell találni, amely összekapcsolja a terméket a fogyasztóval. A jó sztorik pedig gyakran a fogyasztók ötleteire vagy a fogyasztási magatartásukban fellelhető motívumokra építenek. A marketingszakma, s különösen a reklámosok, rendkívül járatosak a mítoszok létrehozásában és fenntartásában (Randazzo, 1993), vagy abban, hogy a már meglévő mítoszokra építsenek (Levy, 1981). A mítosz központi kulturális szerepe - narratív „,mese vagy történet”, amely a görög mítosz szóból ered - a világ természetének magyarázata, valamint az adott kultúra társadalmi történéseinek logikus leírása (Stern, 1995).

Roberts (2005), a Lovemarks c. könyv szerzője szerint mesék táplálják a „szeretetmárkákat”, amelyek segítenek megmagyarázni a világot, és értékesebbnek tüntetik fel a szeretett dolgokat. Egy kellő pillanatban elmesélt jó történet ugyanis jelentős mértékben megváltoztathatja a gondolatmenetünket, s ezért óriási értékük van az üzleti világban. Egy történetet szereplők, érzelmek és érzékletes részletek nélkül lehetetlen elmondani. S mivel a történeteket emberek mesélik embereknek, ezért kiváló beleérző és meghallgató képességekkel kell rendelkezni a fogyasztóik élményeinek és történeteinek összegyűjjtéséhez (Roberts, 2005: 90). Andreasen (1985) szerint a kutatást fordított logika alapján kell elvégezni, vagyis először azt kell meghatározni, hogy az eredményeket mire szeretnénk felhasználni. Felhasználók körében készített narratív interjúk egyik célja lehet, hogy megragadja azokat a fogyasztói történeteket, hogy miért érzik a fogyasztók lényegesnek az adott márkát, milyen személyes élményt tudnak hozzákötni. A cél ekkor olyan fogyasztói történettípusok nyerése, amelyek autentikusak, éppen ezért hihetők más fogyasztók számára is. Felhasználási területe meglehetősen széles. Amellett, hogy a vállalat információt kap arról, hogy miért tartják a fogyasztók az adott márkának fontosnak, bepillantást kap arról is, hogy miként épül be a márka a fogyasztók életébe. Ezen felül a történetek segítséget nyújthatnak olyan marketingstratégiai lépésekben, mint imázsjavítás, pozícionálás, márkaépítés, reklámkoncepciók kialakítása.

Roberts (2005: 77) szerint olyan jó sztorikat kell keresni, amelyeket gyakran el lehet mondani. A szeretetmárkák mögött ugyanis emlékezetes történetek állnak, a legjobbakból pedig mitikus legendák válnak. A történetmesélés új értelmet ad a márkának, új kapcsolatokat teremt, új érzelmeket kelt.

Levy (1981) úgy látja, hogy a fogyasztók történeteit az irodalomkritikusokhoz hasonlóan kell értelmezni. Stern (1995) azért elemzi a narratívumokat, hogy feltárjon cselekményeket és értékeket olyan tech- nikákkal, amelyeket az irodalmi szövegek vizsgálata során használnak.

A mitikus cselekmények (Stern, 1994), hősök és értékek alaposabb tanulmányozása a fogyasztói magatartás jobb megértéséhez járul hozzá. Levy (1981) azt kérdezi, hogy ha a fogyasztók válaszai történetek (vagy részben azok), akkor hogyan értelmezhetjük azokat? Ha megvizsgáljuk a kapcsolatot a fogyasztók történeteiben található mítoszok, valamint az irodalomban és más szövegben található mítoszok között, akkor mélyebben meg tudjuk érteni a fogyasztói szövegeket (Stern, 1995). Ezáltal jobban megérthetjük a fogyasztókat, akikből érzelmi reakciókat váltanak ki azok a történetek, amelyeket mesélnek. Ez azért is lényeges, mivel „,számos személyiség számára a legforróbb drámai pillanatokban kristályosodik ki az identitás érzése. Az elsöprő győzelem, a szembenézés a veszedelemmel, az elvesztett szerelmes visszatérése az, ami az embert az én érzésével a leghevesebben eltöltheti." (Gergen - Gergen, 2001:87)

William James szerint ,a vallás tanulmányozásakor a legvallásosabb embert kell tanulmányoznunk annak legvallásosabb pillanatában" (idézi: Bruner, 2001: 30). Ez azt jelenti, hogy a történetek válogatásakor törekedni kell arra, hogy a meglehetősen színes palettából a legjellegzetesebbeket mutassuk be, amelyik hihetőnek, valamint érdekesnek is tünnek egyúttal.

Douglas és Isherwood (1980) szerint még a javak puszta használatánál is nagyobb örömet jelent megvitatni a fogyasztáshoz kapcsolódó témákat és történeteket. Wolburg (2001) arra a következtetésre jutott, hogy az alkoholfogyasztás fantasztikus történeteket eredményez, s az egyetemi élet legjobb emlékei hozzá kötődnek. A közösségi funkció kiterjesztése az italozást követő sztorik mesélése. Ebben az értelemben az alkoholfogyasztás előnyei nem azonnaliak, hanem napokkal, hetekkel vagy akár évekkel később lehet átélni azokat. A történeteket ugyanis akkor mesélik, ha józanok, s az összetartozás érzését kívánják erősíteni.

Hofmeister Tóth és Simányi (2005) a fogyasztás szubjektív értelmezését vizsgálja. Ehhez Thomson, Locander és Pollio (1989) speciális interjú módszerét használják, melynek lényege, hogy a nyitó kérdésen kívül a kutató nem készül előre meghatározott kérdésekkel, hanem hagyja, hogy a megkérdezett saját élményei szerint szője a beszélgetést. Az interjú során feltett kérdések elsősorban az élmények pontosabb megértésére irányulnak ( $\mathrm{pl}$. „Hogyan érezte magát ebben a szituációban?”), a „Miért?” kérdés azonban tilos, mert az arra kényszeríti a válaszadót, hogy racionalizáljon egy viselkedést, amit egyébként nem tenne (pl. „Miért nem hasonlítja össze az árakat?"). 
Az interjú készítésnek ez az irányzata nagyobb szabadságot biztosít az alanynak abban, hogy mondanivalóját saját maga strukturálja, s kevésbé az interjú vezérfonala determinálja a kérdezett gondolkodásmódját. Ez azért is lényeges, mivel - ahogy László (2005: 80) megjegyezte - ,az interjúk sok tekintetben álnarratívumok, amelyekben a történet fonalát részben az interjúkészítő fonja - abból a célból, hogy valamiféle szőttes keletkezzék".

Az epizodikus interjú (Flick 1998, 2000) a narratív életútinterjú és a strukturált interjú előnyeit ötvözi. Az elsősorban pszichológiában, pszichiátriában alkalmazott hagyományos életútinterjúk akár több órát is igénybe vehetnek, és annak érdekében, hogy a válaszadó saját maga dönthessen az események fontosságáról, szinte alig nyújtanak lehetőséget a kutatói beavatkozásra. $\mathrm{Ez}$ óriási adatmennyiséget eredményez, amelynek jelentős része az adott témára vonatkozó kutatói kérdés esetén felesleges (ami a pszichiátriában elkerülhetetlen a diagnózis felállításához, az nem biztos, hogy ugyanolyan releváns a marketingben). A módszer további korlátja, hogy csak a szűkebb értelemben vett narratív elemek (időbeli egymásutánban zajló események) kerülnek elemzésre, a leíró részeket kizárva. A strukturált kérdések esetében éppen a narratív jelleg veszik el, mely kutatási probléma idődimenziójának megértéséhez szükséges (Hofmeister Tóth - Simányi, 2005).

Az epizodikus interjú módszere a narratív emlékeket a narratív életútinterjúhoz hasonló módszerrel tárja fel, azonban jelentősen behatárolja a történet témáját, ezzel csökkentve az interjú időtartamát, és a felesleges adatgyűjtést. Hofmeister Tóth és Simányi (2005) a múltbeli fogyasztási élményeket, azok időbeli változását, valamint az aktuális fogyasztási szituációkat (vásárlások, mások fogyasztási szokásaival való találkozás stb.) kutatja.

Összességében a fogyasztási kultúra (pontosabban kultúrák) megismeréséhez elfogadhatjuk Michelle Rosaldo (1984: 140) antropológus elvét, aki szerint: a „konstruált kultúra kevésbé műtermékek és propozíciók, szabályok, sematikus programok vagy hiedelmek kérdése, mintsem asszociatív láncoké és képeké, amelyek meghatározzák, mi mivel köthető ésszerűen öszsze, és ezt olyan kollektív történetek alapján tanuljuk meg, amelyek az aktor világában értelmes, koherens és valószínű dolgok természetéről adnak képet."

\section{Reklámokhoz kapcsolódó történetek elemzési lehetőségei}

A hagyományos elméletek tipikusan rögzített ingerek sokaságaként értelmezik a reklámokat, amelyek előre pontosan meghatározható információkat tartalmaznak. A fogyasztókat pedig identitás nélküli, magá- nyos alanyokként kezelik, akik csupán korlátozott módon képesek reagálni a reklámokra, s legfőbb céljuk, hogy ítéletet alkossanak a márkákról (információs megközelítés).

A reklámok hatása a különböző termékekhez kötődő fogyasztói attitűdökre és hitekre komplex és nehezen megérthető (Domzal - Kernan, 1992). Elképzelhető, hogy léteznek reklámhatások, de ezeket nehéz feltérképezni, illetve mérni. Az idevonatkozó kutatások legnagyobb része információfeldolgozási nézőpontból készült, ami azt jelenti, hogy a reklámot a termékről nyújtott információnak tekintik, amit az emberek aztán a vásárlási döntési folyamatba építenek be. Az elmélet, hogy a reklámok „tesznek valamit” a fogyasztóval, a reklámhatásosság mérések (úgymint visszaidézés, felismerés valamint a reklámokkal kapcsolatos attitűdök) alapfeltevése maradt. A posztpozitivista kutatók ezzel szemben új utakat tárnak fel a reklámhatásosság vizsgálatához (Mick - Buhl, 1992; Thompson et al., 1994).

Mick és Buhl (1992) a szemiotikát és az antropológia elméleteit alapul véve állítják, hogy a reklámok félig-meddig képzeltek, kulturálisan létrehozott szimbólumrendszerek, amelyekben a termékeket stratégiai szempontok alapján rendelték hozzá színhelyekhez, kellékekhez, emberekhez és akciókhoz. Tehát a fogyasztók úgy interpretálják a reklámokat, mint a világ, illetve saját maguk megismerésének egyik fó útját (McCracken, 1986).

A jelentésalapú megközelités szerint a fogyasztók a reklámoknak különböző jelentéseket tulajdonítanak, a személyes érdekek, valamint a reklámok kulturális körülmények közötti interpretálásának eredményeként (1. ábra). Ez a megközelítés a reklám átélésének szubjektivitását hangsúlyozza, ami a reklám szimbolikájának és kiterjesztő tartalmának, a fogyasztó élettörténetének, valamint az őt körülvevő szociokulturális közegnek tulajdonítható (Mick - Buhl, 1992). A fogyasztók meglehetősen eltérő módon tekintenek a világra, ezért a velük kapcsolatos jelenségeket úgy kell tanulmányozni, ahogy ők egyénileg élnek és tapasztalnak.

\section{A modell a következő összetevőket tartalmazza:}

Elvárások horizontja: A kitalált szövegeknek nincsen előre meghatározott értelme, hanem az olvasók aktualizálják az olvasottakat, az összefüggő értelmezés érdekében, ahol szükséges, betöltik ,az üres réseket”. Az elvárások horizontja az egyén szociokulturális és személyes környezetéből, valamint előzetes, szövegértelmezéssel kapcsolatos tapasztalataiból épül fel (pl. regények, reklámok).

Elettémák (Life Themes): Pszichológusok (mint például Allport és Kelly) megfigyelték, hogy az emberek strukturálják céljaikat annak érdekében, hogy koherenciát tudjanak alkotni 
A reklámok átélésének jelentésalapú modellje

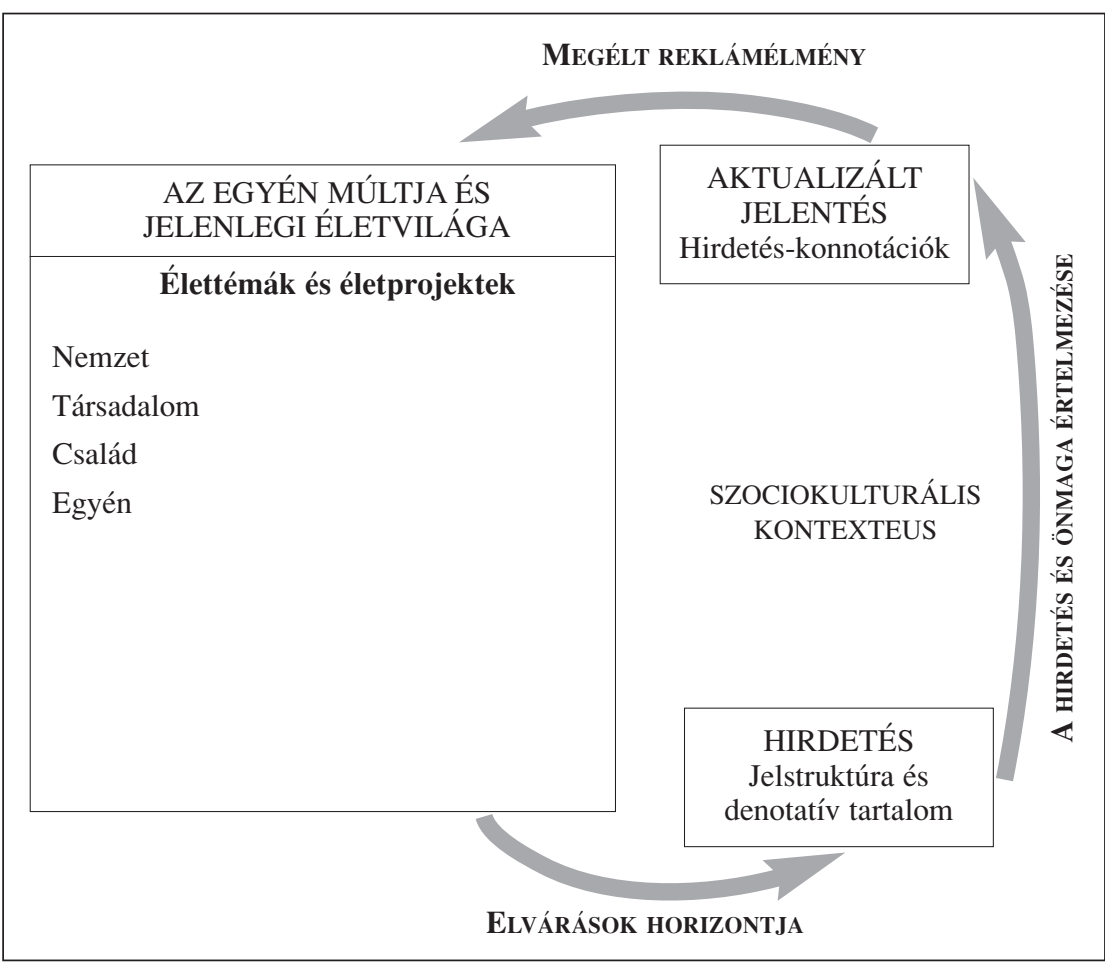

Forrás: Mick és Buhl (1992)

saját életükre nézve. A dönto élethelyzetek (pl. a család pénzügyi helyzete, személyközi kapcsolatok, korai megrázó élmények vagy a neveltetés) olyan mély, létfontosságú dolgok, amelyekhez az a napi események kapcsán - tudatosan vagy tudattalanul - visszanyúlunk. Kutatások kimutatták, hogy az élettémák korlátozott számban léteznek az egyes egyénen belül, s viszonylag kevéssé térnek el ahhoz képest, ami már egyszer kialakult (Csikszentmihalyi - Beattie, 1979).

Életprojektek (Life Projects): Az élettémákkal ellentétben az életprojektek állandó mozgásban vannak, aminek a körülményekben, illetve az életciklusban bekövetkező változások szabnak irányt. McCracken (1987) úgy jellemezte az életprojekteket, mint specifikus fogalmak (pl. férfiasság) kifejlesztését, kidolgozását, valamint elrendezését a kulturálisan létrehozott alternatívák területéről. Így az életprojektek önmagunkkal, illetve kiterjesztett lényünkkel kapcsolatos jelentésekre vonatkoznak (magánszféra, otthon és család, közösség és karrier) és nem másokkal szembeni jelentésekre.

Nemzeti szint: nemzeti jelleggel, illetve a nemzetköziséggel összefüggő jelentések.

Társadalmi szint: lakókörnyezettel, csoportokkal, karrierrel kapcsolatos jelentések.

Családi szint: családtagokhoz (szülők, testvérek, házastársak és gyerekek) kötődő jelentések.

Magánszféra: individuális emberi lénynek lenni (személyes aktivitások és érdeklődési kör).

Jelstruktúra és denotatív tartalom: Szemiotikai értelemben minden reklámnak két alapvető jelentése van: a jelstruktúra és a denotatív tartalom. Ez a reklám elsődleges jelentése, ami
1. ábra általános értelemben vett és nyilvánvaló. Például függetlenül attól, hogy hány szögből lehet egy adott fotót elkészíteni, egy sivatagban ülő férfi képe mindenki számára hasonló elsődleges jelentéssel bír.

Aktualizált jelentés, konnotációk: A magasabb rendű, másodlagos vagy konnotatív jelentés (mint például az, hogy az öltöny és a környezet azt sugallja, hogy az ember a képen egy merész bürokrata) sokkal inkább változó és előre meghatározhatatlan, különösen az egyes fogyasztó szintjén.

Az élettémákat, illetve a mítoszokat nehéz megfogni a hagyományos kutatási módszerek segítségével. Mick és Buhl (1992) elmeséltette a kutatás alanyaival, hogy mi történik a hirdetésben, valamint milyen érzelmeket, gondolatokat kapcsolnak hozzá. Aztán az élettörténettel kapcsolatos interjú során feltárták a megkérdezettek hátterét, családtörténetét, érdeklődési körét, életének lényeges eseményeit, valamint az adott termék fogyasztásával kapcsolatos tapasztalatokat. A Mick és Buhl (1992) által kifejlesztett jelentésalapú eljárás segítséget nyújt azon marketinges szakemberek számára, akik meg szeretnék érteni a fogyasztók termékeknek tulajdonított jelentéseit. A koncepciók során ezt a tudást felhasználva a potenciális fogyasztó pedig sokkal könnyebben tud azonosulni a termékkel vagy a szolgáltatással. A módszer társadalmi célú kampányok alkotói számára is hasznos lehet, hiszen ennek segítségével ki lehet alakítani a különböző profilokat, valamint a dohányosok/alkoholfogyasztók stb. tipológiáját. A szakemberek tehát hasznosíthatják a mítoszok azonosításából nyert ismereteket annak érdekében, hogy ezeket a reklámokban alkalmazzák. Bár Mick és Buhl (1992) kutatási módszere hosszadalmas (mivel élettörténetekre épít), a modell filozófiája azonban rendkívül inspiratív.

A posztmodern marketing abból az előfeltevésből indul ki, hogy a reklám szövege nem stabil, és nem csak egyetlen értelmezés lehetséges, a szöveg olvasata ezért sokféle lehet, s ez a szöveg értelmezőjétől függ (Brown et al., 1999). Ez az elmélet természetesen táplálkozik a posztmodern filozófusok gondolataiból. Derrida (1976) például úgy véli, hogy nincs rögzített jelentés, a jelentés állandó mozgásban van. Korábban egyébként már a pszichológus Kelly (1955) is utalt rá, hogy az emberek különböznek egymástól abban, hogy miként konstruálják a világot. Hirschman és Thompson (1997) szerint a 
megkérdezettek a reklámot projektív eszközként használják annak érdekében, hogy jelentésüket saját magukra tudják átvinni. A jelentések aztán összefonódnak az egyén önmagáról alkotott fogalmával, és reklám-élmény jön létre. Parker (1998) eredményei is azt mutatják, hogy az emberek kapcsolatot teremtenek a reklámok, valamint életük alapvető eseményei között. Parker (1998) bizonyítékokat talált rá, hogy a reklámozók képesek életmotívumokra, valamint a termékeket, illetve szolgáltatásokat érintő mítoszokra rácsatlakozni.

Mitev és Horváth (2005) az alkoholreklámok fogyasztói megítélését, valamint fogyasztói gondolkodást befolyásoló szerepét elemezték. Azt vizsgálták, hogy a reklám felidézése során megélt élmények miként kapcsolódnak a mindennapi személyes élményekhez, és milyen viszonyban állnak egymással. A kutatás során egyetemisták alkoholreklámokhoz kapcsolódó narratívumait elemezték. Ez a korosztály már szabadabban, különösebb korlátok nélkül mesélhet az átélt eseményekről, s ezáltal eleven és tapasztalatokkal dúsított, meglehetósen változatos narratívumokhoz jutottak. Az alapötlet, hogy Frye kategóriái alapján a fogyasztók történetei és a reklámok alkotó módon elemezhetők, Sterntől (1995) származik. Koncepcióját azonban továbbfejlesztették, mivel Sterntől eltérően az átélt reklámélményeket elemezték, s nem maguk kerestek a kategóriákhoz reklámokat. Mitev és Horváth (2005) rámutattak arra, hogy a reklámokban használt mítoszok önálló életet kezdenek élni annak függvényében, hogy a fogyasztók képesek-e életük valamilyen jelentős eseményét hozzákapcsolni. A reklámmítoszok tehát jóval mélyebben hatnak, mint amit a széles körben elterjedt reklám-vizsgálatok képesek kimutatni. Eredményeik felhívják a figyelmet a reklám gondolkodásmód- és magatartás-formáló hatásaira, amelyek más módszerekkel csak nehezen tárhatók fel.

\section{Narratív elemzési minták}

A narratívumok elemezhetők induktív vagy deduktív módon. Induktív eljárás során egészen addig olvasgatjuk a szöveget, amíg fel nem fedezünk benne bizonyos szempontokat, amelyek a strukturálást segítik. Azonban új fogalmi konstruktumot kizárólag a szövegekből kialakítani nem biztos, hogy lehetséges, ugyanakkor befolyásolják a gondolkodást a kutató fejében előzetesen létező struktúrák is. A deduktív eljárás során egy már létező konstruktumot használunk az elemzés során (a pszichológiai tartalomelemzésben például ez jóval gyakoribb eset). Ennek során egy már korábban használt, kialakított konstruktum meglétét mutatjuk ki (Ehmann, 2003: 68).

A narratívumok rendkívül változatos és sokféle módon elemezhetők ${ }^{2}$, a cikkben csupán háromféle egymást jól kiegészítő és erősíto - logikát mutatunk be: a rituálé összetevőit, Frye tipológiáját, valamint Propp morfológiáját (2. táblázat).

Ezek az elemzési minták alapvetően deduktívak, hiszen már létező konstruktumokat (Driver, 1991; Rook, 1985; valamint Frye, 1998) használunk. Annyiban lehet induktív, hogy a szakaszok elnevezését a történetek olvasgatása során alakítjuk ki. Ennek megfelelően elsősorban a rituálé összetevői, valamint a történetek szakaszai alapján történik a kódolás ${ }^{3}$.

Valójában csak elemzési keretet jelölünk ki, de az egész olyan, mintha egy színdarabot néznénk: láthatjuk, hogy a főhősök milyen megpróbáltatásokon vesznek részt, milyen eszközöket vesznek igénybe, s kik veszik őket körül. A cselekményeket a rendező világítja meg, így kapnak a jelenetek komikus, tragikus, esetleg ironikus színezetet. Figyelemmel kísérhetjük azt is, hogy a színek hogyan váltják egymást, sőt a műsorfüzetet lapogatva még azt is megtudhatjuk, hogyan értelmezi a rendező a jeleneteket. Ez azonban nem jelen-

2. táblázat

Narratívumok elemzéséhez használt néhány közelítés

\begin{tabular}{|c|c|c|c|c|}
\hline $\begin{array}{l}\text { Elemzési } \\
\text { keret }\end{array}$ & Leírása & Cél & $\begin{array}{l}\text { Fontosabb } \\
\text { irodalmak }\end{array}$ & $\begin{array}{l}\text { Használható } \\
\text { kódok }\end{array}$ \\
\hline $\begin{array}{l}\text { Rituálé } \\
\text { összetevői }\end{array}$ & $\begin{array}{l}\text { Rituális magatartás négy komponense (Rook, 1985): } \\
\text { rituális tárgyak, rituális forgatókönyv, rituális szere- } \\
\text { pek, rituális közönség. A rituálék „,társadalmi ajándé- } \\
\text { kokhoz” juttatják az abban résztvevőket (Driver } \\
\text { (1991) rend, közösségi élmény, átalakulás. }\end{array}$ & $\begin{array}{l}\text { A rituálé összetevőinek } \\
\text { beazonosítása a fogyasz- } \\
\text { tók történeteiben. }\end{array}$ & $\begin{array}{l}\text { Driver (1991), } \\
\text { Rook (1985), } \\
\text { Levy (1983) }\end{array}$ & $\begin{array}{l}\text { A rituálé összetevői } \\
\text { alapján. }\end{array}$ \\
\hline $\begin{array}{l}\text { Frye } \\
\text { tipológiája }\end{array}$ & $\begin{array}{l}\text { Négy alapműfaj különböztethető meg: komédia, ro- } \\
\text { mánc, tragédia, irónia. Ahogyan az irodalmi cselek- } \\
\text { mények feloszthatók különféle kategóriákra, úgy a } \\
\text { fogyasztók cselekedetei is hasonlóan értelmezhetők. }\end{array}$ & $\begin{array}{l}\text { Történetek strukturálása } \\
\text { Frye tipológiája alapján. } \\
\text { Az egyes műfajokba } \\
\text { sorolt narratívumok } \\
\text { jellemzőinek feltárása. }\end{array}$ & $\begin{array}{l}\text { Frye (1998), Stern } \\
\text { (1995), Gergen és } \\
\text { Gergen }(2001), \\
\text { Rokeach }(1973)\end{array}$ & $\begin{array}{l}\text { Nincsenek külön } \\
\text { kódok: a története- } \\
\text { ket műfaji jellegze- } \\
\text { tességek alapján } \\
\text { soroljuk be. }\end{array}$ \\
\hline $\begin{array}{l}\text { Propp mor- } \\
\text { fológiája }\end{array}$ & $\begin{array}{l}\text { A mesék tartalma rövid mondatokba sűríthető. } \\
\text { Különböző szakaszok tárhatók fel. }\end{array}$ & $\begin{array}{l}\text { A fogyasztás tipikus sza- } \\
\text { kaszainak beazonosítása. }\end{array}$ & Propp (1995) & $\begin{array}{l}\text { A történet szakaszai } \\
\text { alapján. }\end{array}$ \\
\hline
\end{tabular}


ti annak kizárólagos meghatározását, hogy a nézők hogyan gondolkodjanak a darabról. Minden olvasat másfajta interpretációt eredményez. „Nem tudunk elmagyarázni egy történetet, csak annyit tehetünk, hogy elmondjuk különféle interpretációit” (Bruner, 2004: 114).

$$
* * *
$$

A narratív megközelítés olyan filozófia, amely kellően színesíti a marketing és más menedzsmenttudományok módszertani palettáját. Lehetővé teszi, hogy emberközelibb nézőpontból tekintsünk egy-egy problémára, és a gyakorlatban is alkalmazható eredményeket kapjunk. A kutatásmódszertant övező mítoszok olykor-olykor megújításra szorulnak.

\section{Felhasznált irodalom}

Andreasen, A. R. (1985): „Backward” Marketing Research. Harvard Business Review, May-June, 176-182.

Banister, P. - Burman, E. - Parker, I. - Taylor, M. - Tindall, C (1994): Qualitative Methods in Psychology. A Research Guide. Open University Press, Buckingham

Barthes, R. (1977): Image, music, text. Fontana, New York

Bokor A. (2000): Szervezeti kultúra és tudásintegráció: A termékfejlesztés problémája. $\mathrm{PhD}$ értekezés, BKÁE, Budapest

Brown, S. - Stevens, L. - Maclaran, P. (1999): I Can't Believe It's Not Bakhtin!: Literary Theory, Postmodern Advertising, and the Gender Agenda. Journal of Advertising, Vol. XXVIII, Number 1, Spring, 11-24.

Bruner, J. (2001): A gondolkodás két formája. In: László J. és Thomka B. szerk.: Narratívák 5. Narratív pszichológia. Kijárat Kiadó, Budapest., 27-57.

Bruner, J. (2004): Az oktatás kultúrája. Gondolat Kiadó, Budapest

Bush, A. J. - Bush, V. D. (1994): The Narrative Paradigm as a Perspective for Improving Ethical Evaluations of Advertisements. Journal of Advertising, 23/3, 31-41.

Csikszentmihalyi, M. - Beattie. O.V. (1979): Life Themes: A Theoretical and Empirical Exploration of Their Origins and Effects. Journal of Humanistic Psychology, 19 (1), 45-63.

Derrida, J. (1976): Of Grammatology. Johns Hopkins University Press, Baltimore

Domzal, T. J. - Kernan, J. B. (1992): Reading Advertising: The What and How of Product Meaning. Journal of Consumer Marketing, 9 (4), 48-64.

Douglas, M. - Isherwood, B. (2003): A javak használatának változatai. In: Wessely Anna szerk.: A kultúra szociológiája. Osiris Kiadó - Láthatatlan Kollégium, Budapest

Driver, T. (1991): The Magic of Ritual. Harper Collins, New York

Ehmann B. (2002): A szöveg mélyén: A pszichológiai tartalomelemzés. Új Mandátum Kiadó, Budapest

Feyerabend, P. (1975): Against Method. Verso, London

Fisher, W. (1984): Narration as a Human Communication Paradigm: The Case of Public Moral Argument. Communication Monographs, 51 (March), 1-18.

Flick, U. (2000): Episodic interviewing. In: M. W. Bauer and G. Gaskell eds.: Qualitative researching with text, image and sound. Sage, London, 75-92.

Flick, U. (1998): An introduction to qualitative research. Sage, London

Frye, N. (1998): A kritika anatómiája. Helikon Kiadó, Budapest

Gelei A. (2002): A szervezeti tanulás interpretatív megközelítése. PhD értekezés, BKÁE, Budapest
Gergen, K. J. - Gergen, M. M. (2001): A narratívumok és az én mint viszonyrendszer. In: László J. és Thomka B. szerk.: Narratívák 5. Narratív pszichológia. Kijárat Kiadó, Budapest., 77-119.

Gummesson, E. (2003): All research is interpretive! The Journal of Business \& Industrial Marketing, 18, 6/7, 482-492.

Haraway, D. (1984): Primatology is politics by other means. In: Bleier, R. (ed.): Feminist approaches to science. Pergamon, London

Heller Á. (1997): Elmélkedések a hiszékenységről. Magyar Tudomány, 8.

Hirschman, E. C. (1986): The Effect of Verbal and Pictorial Advertising Stimuli on Aesthetic, Utilitarian, and Familiarity Perceptions. Journal of Advertising, 15 (June), 27-34.

Hirschman, E. C. - Thompson, C. (1997): Why Media Matter: Toward a Richer Understanding of Consumer's Relationships with Advertising and Mass Media. Journal of Advertising, 26(1), 43-60.

Hofmeister Tóth Á. - Simányi L. (2005): A fogyasztói társadalom kutatásának lehetőségei Magyarországon. MOK, Győr, CD

Kelly, G. A. (1955): The psychology of personal constructs. Vol. 1. Norton, New York

László J. (2005): A történetek tudománya: Bevezetés a narratív pszichológiába. Új Mandátum Könyvkiadó, Budapest

László J. - Thomka B. (szerk.) (2001): Narratívák 5. Narratív pszichológia. Kijárat Kiadó, Budapest

Levy, S. J. (1981): Interpreting Consumer Mythodology: A Structural Approach to Consumer Behavior. Journal of Marketing, 45, Summer, 49-61.

MacIntyre, A. (1999): Az erény nyomában. Osiris Kiadó, Budapest

Malhotra, N. K. (2001): Marketingkutatás. Műszaki Könyvkiadó, Budapest

McCracken, G. (1986): Culture and Consumption: A Theoretical Account of the Structure and Movement of the Cultural Meaning of Consumer Goods. Journal of Consumer Research, 13, June, 71-84.

McCracken, G. (1987): Advertising: Meaning or Information? In: Advances in Consumer Research, Vol. 14. ed. M. Wallendorf and P. Anderson, Provo, UT: Association for Consumer Research, 121-124.

Mick, D. - Buhl, C. (1992): A Meaning-Based Model of Advertising Experiences. Journal of Consumer Research, 19, December, 317-338.

Mitev A. (2005): A társadalmi marketing elméleti és empirikus kérdései: Egyetemisták alkoholfogyasztási történeteinek narratív elemzése. $\mathrm{PhD}$ értekezés. Budapesti Corvinus Egyetem

Mitev A. - Horváth D. (2005): Mítoszok sodrásában: Az alkoholreklámokhoz kapcsolódó fogyasztói narratívumok strukturális elemzése Frye kategóriái alapján. Marketing és Menedzsment, 6, 20-32.

Mulkay, M. (1985): The word and the World: Explorations in the Form of Sociological Analysis. Allen and Unwin, London

Oatley, K. (1992): Best laid schemes: The psychology of emotions. Cambridge University Press, New York

Onega, S. - Landa, J. A. G. eds. (1996): Narratology: An introduction. Longman, London

Parker, B. J. (1998): Exploring Life Themes and Myths in Alcohol Advertisements through a Meaning-Based Model of Advertising Experiences. Journal of Advertising Vol. 27, No. 1, Spring, 97-112.

Propp, V.J. (1995): A mese morfológiája. Osiris-Századvég, Budapest

Radácsi L. (2003): „One best way” a menedzsmenttudományos kutatásokban - Gondolatok a kvalitatív módszertan hazai helyzete ürügyén. Vezetéstudomány, 10. szám, 4-12.

Randazzo, S. (1993): Mythmaking on Madison Avenue: How Advertisers Apply the Power of Myth and Symbolism to Create Leadership Brands. Probus, Chicago 
Roberts, K. (2005): Lovemarks: Jövő a márkák után. Magyar Könyvklub, Budapest

Rokeach, M. (1973): The Nature of Human Values. Free Press, New York

Rosaldo, M. (1984): Toward an Antrophology of Self and Feeling. In: Schroeder, R. and Le Vine, R. eds.: Culture Theory: Essays on Mind, Self and Emotion. Cambridge University Press, Cambridge, 137-158.

Rook, D.W. (1985): The Ritual Dimension of Consumer Behavior. Journal of Consumer Research, 12, December, 252-264.

Sarbin, T. R. (2001): Az elbeszélés mint a lélektan tő-metaforája. In: László J. és Thomka B. szerk.: Narratívák 5. Narratív pszichológia. Kijárat Kiadó, Budapest, 59-76.

Steel, J. (2002): Igazság, hazugság, reklám. Sanoma Kiadó, Budapest

Stern, Barbara (1988): How Does an Ad Mean? Language in Services Advertising. Journal of Advertising, 17 (2), 3-14.

Stern, B. B. (1994): Classical and Vignette Television Advertising Dramas: Structural Models, Formal Analysis, and Consumer Effects. Journal of Consumer Research, 20 (March), 601-615.

Stern, B. B. (1995): Consumer Myths: Frye's Taxonomy and the Structural Analysis of Consumption Text. Journal of Consumer Research, Vol. 22, September, 165-185.

Tashakkori, A. - Teddlie, Ch. (1998): Mixed Methodology. Combining Qualitative and Quantitative Techniques. Applied So- cial Research Methods, Vol. 46. Sage Publications, Thousand Oaks

Thompson, C. J. - Locander, W. B. - Pollio, H. R. (1989): Putting consumer experience back into research: The philosophy and method of existential-phenomenology. Journal of Consumer Research, 16, (September), 133-146.

Thompson, C. J. - Pollio, H. R. - Locander, W. B. (1994): The Spoken and the Unspoken: A Hermeneutic Approach to Understanding the Cultural Viewpoints that Underlie Consumers' Expressed Meanings. Journal of Consumer Research, 21, December, 432-452.

Van Maanen, J. (1988): Tales of the field. On writing ethography. University of Chicago Press, Chicago

\section{Lábjegyzetek}

Az eredmények bizonyos esetekben kvantifikálhatók (lásd erről részletesen: Ehmann, 2002; László, 2005), azonban most a kvalitatív jelleget szeretnénk hangsúlyozni.

2 További lehetőségekhez kiváló támpontot adnak Ehmann (2002) és László (2005) művei.

3 Megközelítésekről részletesebb leírást lásd Mitev (2005). 